\title{
J. Barrau, Bible, lettres et politique. L'Écriture au service des hommes à l'époque de Thomas Becket
}

\section{G. Matteo Roccati}

\section{(2) OpenEdition}

1 Journals

\section{Édition électronique}

URL : http://journals.openedition.org/studifrancesi/9886

DOI : 10.4000/studifrancesi.9886

ISSN : 2421-5856

Éditeur

Rosenberg \& Sellier

\section{Édition imprimée}

Date de publication : 1 août 2017

Pagination : 333

ISSN : 0039-2944

\section{Référence électronique}

G. Matteo Roccati, « J. Barrau, Bible, lettres et politique. L'Écriture au service des hommes à l'époque de Thomas Becket », Studi Francesi [En ligne], 182 (LXI | II) | 2017, mis en ligne le 18 octobre 2017, consulté le 06 janvier 2021. URL : http://journals.openedition.org/studifrancesi/9886 ; DOI : https:// doi.org/10.4000/studifrancesi.9886

Ce document a été généré automatiquement le 6 janvier 2021.

\section{(c) $(1) \ominus$}

Studi Francesi è distribuita con Licenza Creative Commons Attribuzione - Non commerciale - Non opere derivate 4.0 Internazionale. 


\title{
J. Barrau, Bible, lettres et politique. L'Écriture au service des hommes à l'époque de Thomas Becket
}

\author{
G. Matteo Roccati
}

\section{RÉFÉRENCE}

JULIE BARRAU, Bible, lettres et politique. L'Écriture au service des hommes à l'époque de Thomas

Becket, Paris, Classiques Garnier, 2013, «Bibliothèque d'histoire médiévale» 8, 574 pp.

1 L'objectif de l'ouvrage «est d'étudier les échanges épistolaires dans leur apport à l'histoire sociale et politique, avec l'accent mis fortement sur le fonctionnement d'une sociabilité cléricale fondée sur un univers culturel commun» (p. 58), en prenant comme fil conducteur l'usage de la Bible dans les lettres qui documentent le conflit entre Thomas Becket et Henri II: c'est-à-dire «les événements de 1163-1173, du début de la crise ouverte entre Thomas et Henri II à la canonisation du martyr par Alexandre III» (p. 50). Le corpus sur lequel l'étude a été menée est constitué de plusieurs recueils, parmi lesquels notamment les correspondances de Thomas Becket, Jean de Salisbury, Gilbert Foliot, Arnoul de Lisieux, maître David de Londres, Herbert de Bosham, Alain de Tewkesbury, Pierre de Celle (cf. pp. 50-58).

2 Après l'introduction (pp. 11-100), la première partie traite de la Bible en situation épistolaire (pp. 102-340), la deuxième des relations entre Bible et droit canon (pp. 343-478). Conclusion aux pp. 479-482, Bibliographie aux pp. 483-552, index des références et allusions bibliques aux pp. 553-558, des notions aux pp. 559-561, des noms de personnes aux pp. 563-568. 